\title{
DINAMIKA USAHA DAN KEPUASAN PENGUNJUNG AGROWISATA KAMPOENG BANYUMILI, KABUPATEN SEMARANG
}

\section{BUSINESS DYNAMICS AND SATISFACTION OF VISITORS AGROTOURIISM KAMPOENG BANYUMILI, DISTRICT SEMARANG}

\author{
ANDREAS SIMORANGKIR ${ }^{1 *}$, MARIA ${ }^{2}$ \\ ${ }^{1}$ Program Studi Agribisnis, Fakultas Pertanian dan Bisnis \\ ${ }^{2}$ Staf Pengajar Program Studi Agribisnis, Fakultas Pertanian dan Bisnis \\ Universitas Kristen Satya Wacana, Jl. Diponegoro 56-60 Salatiga 50711 \\ *Email: andreassimorangkir03@gmail.com
}

\begin{abstract}
ABSTRAK
Usaha jasa agrowisata semakin banyak bermunculan di wilayah Jawa Tengah dan ini membuat pelaku agrowisata harus dapat mempertahankan konsumen agar usaha dapat terus berkembang. Penelitian ini bertujuan untuk mengetahui dinamika usaha serta hubungan kualitas pelayanan, fasilitas, lokasi dan promosi terhadap kepuasan pengunjung Agrowisata Kampoeng Banyumili. Penelitian ini dilakukan pada bulan November s/d Desember 2019 di Agrowisata Kampoeng Banyumili. Penelitian ini menggunakan dua jenis penelitian, deskriptif kuantitatif dan kualitatif. Analisis data yang digunakan adalah korelasi rank spearman dan triangulasi sumber. Hasil penelitian menunjukkan bahwa variabel kualitas pelayanan, fasilitas dan promosi memiliki tingkat hubungan yang sedang dan positif serta berkorelasi signifikan terhadap kepuasan pengunjung, untuk variabel lokasi memiliki tingkat hubungan yang kuat dan positif serta berkorelasi signifikan terhadap kepuasan pengunjung. Sedangkan dinamika usaha Agrowisata Kampoeng Banyumili berada pada tahap kestabilan. Adapun hal yang harus diperhatikan pihak pengelola adalah penambahan petunjuk arah didalam lokasi Agrowisata Kampoeng Banyumili, agar pengunjung lebih mudah menemukan fasilitas sehingga, pengunjung akan merasa nyaman dan puas pada saat berwisata.
\end{abstract}

Kata Kunci: Kualitas Pelayanan, Fasilitas, Lokasi, Promosi, Kepuasan Pengunjung, Dinamika Usaha.

\section{ABSTRACT}

Agro-tourism service businesses are increasingly appearing in the Central Java region, making agrotourism actors must be able to retain consumers so that businesses can continue to grow. This study aims to determine the dynamics of business and the relationship of service quality, facilities, location and promotion of the satisfaction of Kampoeng Banyumili Agrotourism visitors. This research was conducted from November to December 2019 in Kampoeng Banyumili Agro-tourism. This research uses two types of research, quantitative and qualitative descriptive. Analysis of the data used is the Spearman rank correlation and source triangulation. The results showed that the variables of service quality, facilities and promotions have a moderate and positive level of relationship and have a significant correlation to visitor satisfaction, for location variables have a strong and positive relationship level and have a significant correlation to visitor satisfaction. While the dynamics of the Kampoeng Banyumili Agro-tourism business is in the stability stage. The manager must pay attention to the addition of directions in the Kampoeng Banyumili Agro-tourism location, so that visitors can more easily find the facilities so, that visitors will feel comfortable and satisfied when traveling.

Keyword : Service Quality, Facilities, Location, Promotion, Visitor Satisfaction, Business Dynamics 


\section{PENDAHULUAN}

Indonesia merupakan negara agraris yang mempunyai keunggulan di berbagai sektor yang bisa dimanfaatkan dalam mengembangkan pertumbuhan ekonomi. Salah satu sektor yang memiliki potensi untuk dikembangkan di Indonesia adalah pariwisata, karena sektor ini memiliki prospek jangka panjang dan sangat cocok untuk dikembangkan dalam memajukan perekonomian masyarakat.

Agrowisata merupakan salah satu sektor pariwisata yang memiliki keunikan tersendiri, karena mengandung kegiatan pertanian dan disajikan dalam bentuk wisata serta diperkuat oleh keberagaman budaya yang masih jarang ditemukan. Keunikan tersebut merupakan aset yang dapat menarik wisatawan baik dari dalam negeri maupun luar negeri untuk berkunjung dan berwisata ke Indonesia. Selain itu sektor agrowisata dapat menjadi media promosi untuk produk pertanian, serta menjadi media pembelajaran bagi pengunjung mulai dari bagaimana kegiatan usaha dibidang pertanian sampai dengan pelestarian lingkungan (Angraeni, 2015). Sedangkan menurut Lopez (2006), mengemukakan bahwa agrowisata adalah kegiatan rekreasi yang telah sukses dalam bidang lingkungan pedesaaan dan budaya dengan harga yang menarik untuk berbagai pasar.

Berdasarkan data yang diperoleh dari Badan Pusat Statistik (BPS) Dinas Kebudayaan dan Pariwisata Propinsi Jawa Tengah periode tahun 2011 - 2015 jumlah wisatawan domestik dan mancanegara terus meningkat ini dapat dilihat pada tabel-1

Tabel-1 Jumlah Wisatawan Mancanegara dan Domestik di Propinsi Jawa Tengah periode tahun 2011 - 2015

\begin{tabular}{cccc}
\hline \multicolumn{4}{c}{ Jumlah Wisatawan Mancanegara dan Domestik (Jiwa) } \\
\hline Tahun & Mancanegara/International & Domestik/Domestic & Jumlah \\
\hline 2011 & 392.895 & 21.838 .351 & 22.231 .246 \\
2012 & 372.463 & 25.240 .021 & 25.612 .484 \\
2013 & 388.143 & 29.430 .609 & 29.818 .752 \\
2014 & 419.584 & 29.852 .095 & 30.271 .679 \\
2015 & 421.191 & 33.030 .843 & 33.452 .034 \\
\hline
\end{tabular}

Sumber : (BPS, 2019).

Tabel-1 menunjukkan bahwa jumlah wisatawan mancanegara dan domestik di Provinsi Jawa Tengah selalu meningkat dari tahun ke tahun. Hal ini disebabkan oleh meningkatnya keinginan masyarakat untuk berkunjung ketempat-tempat wisata 
yang meramaikan sektor pariwisata. Peningkatan jumlah pengunjung menjadi salah satu tolak ukur untuk mengembangkan daerah wisata yang menimbulkan dampak positif bagi perekonomian masyarakat daerah wisata, kondisi ini melibatkan semua pihak yang ada dalam masyarakat mulai dari pengusaha hotel, pengusaha transportasi, jasa wisata, restoran, dan pusat oleh-oleh (Kurnianti dan Tidar, 2018). Peningkatan jumlah pengunjung di Provinsi Jawa Tengah setiap tahun tentunya disebabkan oleh berbagai faktor, salah satunya adalah faktor kepuasan pengunjung terhadap kualitas pelayanan, serta tempat agrowisata yang strategis untuk dikunjungi wisatawan.

Usaha dibidang jasa seperti agrowisata merupakan usaha yang sangat bergantung kepada pengunjung yang datang untuk keberlanjutan usaha tersebut. Jika pengunjung yang datang untuk berwisata merasa kurang puas dengan apa yang disajikan maka minat berkunjung ulang akan hilang bahkan pengunjung akan berpindah ke tempat lain. Hal ini akan berdampak negatif bagi keberlanjutan usaha jasa tersebut. Proses pasang surut usaha juga berpengaruh terhadap keberlanjutan usaha. Dengan mengetahui kendala yang dialami, cara mengatasi, dan pengaruh terhadap lingkungan sekitar akan menghasilkan keberlanjutan usaha tersebut.

Objek agrowisata Kampoeng Banyumili telah beroperasi sekitar lima tahun. Awalnya masih sepi dan sekarang menjadi salah satu objek wisata yang ramai dikunjungi serta adanya dinamika atau proses pasang surut usaha selama wisata ini beroperasi. Oleh karena itu peneliti tertarik untuk melakukan penelitian terhadap dinamika usaha dan kepuasan pengunjung Agrowisata Kampoeng Banyumili Kabupaten Semarang.

\section{METODE PENELITIAN}

Penelitian ini dilaksanakan pada kawasan objek Agrowisata Kampoeng Banyumili yang beralamat di Jalan Raya Muncul, Bandungan, Desa Gedangan, Kecamatan Tuntang, Kabupaten Semarang, Jawa Tengah. Pemilihan lokasi penelitian dilakukan secara sengaja (purposive). Hal ini dikarenakan objek agrowisata Kampoeng Banyumili memadukan nuansa alam pertanian dengan restoran sehingga pengunjung dapat menikmati makanan sambil melihat pemandangan wilayah persawahan serta fasilitas lain (spot foto, pemancingan, dan pusat oleh-oleh). Pengambilan data dilaksanakan pada bulan November 2019 sampai Desember 2019. 
Pengumpulan data dilakukan dengan observasi dan wawancara menggunakan kuesioner. Penelitian ini menggunakan analisis deskriptif kuantitatif. Tujuan penelitian analisis kepuasan pengunjung menggunakan metode survei yaitu cara yang digunakan untuk memperoleh data alamiah dari suatu tempat tertentu (Sugiyono 2013). Dalam penelitian ini, peneliti menggunakan perlakuan data seperti mengedarkan kuesioner kepada pengunjung serta melakukan wawancara mengenai kepuasan pengunjung secara terstruktur.

Sedangkan tujuan penelitian dinamika usaha menggunakan metode kualitatif yang memberikan gambaran mengenai fenomena yang terjadi pada suatu usaha dengan mendeskripsikan dan menceritakan berdasarkan jawaban dari narasumber yang sudah ditentukan melalui kuesioner. Perolehan data dilakukan dengan observasi lapangan dan wawancara mendalam (Indepth interview) (Sugiyono 2013).

Teknik pengambilan sampel yang digunakan pada penelitian ini menggunakan teknik sampling dengan pendekatan non probability sampling adalah teknik pengambilan sampel yang tidak memberikan peluang yang sama bagi setiap atau anggota populasi yang dipilih menjadi sampel. Adapun metode yang di gunakan dalam pengambilan sampel pada penelitian ini dengan purposive sampling. Dengan responden yang memiliki keputusan berkunjung akan dipilih untuk diwawancara.

Jumlah sampel yang diambil dalam penelitian ini sebanyak 50 responden. Hal ini sesuai dengan pendapat Sugiyono (2009), yang menyatakan mengenai ukuran sampel penelitian yang menggunakan analisis multivariate (korelasi atau regresi berganda), maka jumlah anggota sampel minimal 10 kali dari jumlah variabel yang diteliti. Sedangkan tujuan penelitian dinamika usaha, wawancara mendalam dilakukan dengan tokoh kunci (key informant) terkait informasi yang diperlukan seperti pelaku usaha objek agrowisata Kampoeng Banyumili. Adapun karyawan yang paling lama bekerja di Agrowisata Kampoeng Banyumili sebagai informant untuk memperkuat pernyataan tokoh kunci.

Pengolahan data menggunakan software computer Microsoft Exel 2013 untuk input data, SPSS versi 22.0 for windows untuk pengujian tiga uji, yaitu: uji validitas, uji reliabilitas, dan uji korelasi rank spearman untuk mendapatkan keabsahan data. Sedangkan untuk melihat tingkat hubungan digunakan tingkat 
hubungan menurut (Sugiyono, 2014), yaitu 0,00-0,019 tingkat hubungan sangat rendah, 0,20-0,39 rendah, 0,040-0,59 kuat dan 0,80-0,100 sangat kuat. Untuk melihat tingkat signifikansi digunakan uji t dengan signifikansi 0,05. Dan untuk tujuan penelitian dinamika usaha menggunakan teknik triangulasi sumber, yaitu membandingkan kesesuaian data yang diperoleh dari berbagai sumber.

\section{HASIL DAN PEMBAHASAN}

\section{Gambaran Umum Agrowisata Kampoeng Banyumili}

Agrowisata Kampoeng Banyumili merupakan usaha yang dijalankan oleh bapak Sauqi sebagai pemilik sekaligus General Manager (GM) objek Agrowisata Kampoeng Banyumili. Agrowisata ini memanfaatkan potensi alam yaitu memadukan restoran dengan pemandangan panorama wilayah persawahan di kaki gunung Gajah Mungkur dan gunung Telomoyo. Lokasi agrowisata terletak J1. Raya Muncul-Salatiga KM.5 Desa Gedangan antara kota Salatiga dan Ambarawa, yang memiliki luas wilayah keseluruhan sebesar 3,5 ha serta memiliki suhu udara antara $20^{\circ} \mathrm{C}$ sampai dengan $28^{\circ}$ C. Produk yang ditawarkan Agrowisata Kampoeng Banyumili adalah paket outbound, edukasi, camping, dan tempat pertemuan. Pada paket outbound terdapat dua pilihan yang disediakan pihak Agrowisata Kampoeng Banyumili yaitu paket anak dan dewasa (fun game darat, fun game air, fun game lumpur) sudah beserta makan. Untuk paket edukasi disediakan permainan tanam padi, tangkap ikan, perahu, dan flying fox sudah beserta makan. Di agrowisata Kampoeng Banyumili terdapat lapangan yang cukup luas untuk mendirikan tenda dan membuat api unggun bagi para pengunjung yang memesan paket camping. Sedangkan paket pertemuan disediakan meeting room, aula serta live music. Pada hari Jumat sampai Minggu, pengunjung yang datang ke agrowisata Kampoeng Banyumili selalu ramai. Hal ini dikarenakan pada weekend (hari libur) tersedia banyak waktu untuk bersantai. Biasanya pengunjung akan melepas kepenatan setelah beraktivitas selama satu minggu dengan melakukan rekreasi bersama keluarga maupun kerabat. Adapun hari libur di Kampoeng Banyumili adalah hari Senin. 
Tabel-2 Karakteristik Responden Agrowisata Kampoeng Banyumili.

\begin{tabular}{|c|c|c|c|}
\hline No & $\begin{array}{c}\text { Profil Responden Berdasarkan } \\
\text { Usia (Tahun) }\end{array}$ & Frekuensi (Orang) & Persentase (\%) \\
\hline 1 & $18-23$ & 9 & 18,0 \\
\hline 2 & $24-29$ & 12 & 24,0 \\
\hline 3 & $30-35$ & 5 & 10,0 \\
\hline 4 & $36-41$ & 9 & 18,0 \\
\hline 5 & $42-47$ & 6 & 12,0 \\
\hline 6 & $48-53$ & 4 & 8,0 \\
\hline \multirow[t]{3}{*}{7} & $54-59$ & 5 & 10,0 \\
\hline & Total & 50 & 100 \\
\hline & Jenis Kelamin & & \\
\hline 8 & Laki - laki & 21 & 42,0 \\
\hline \multirow{3}{*}{9} & Perempuan & 29 & 48,0 \\
\hline & Total & 50 & 100 \\
\hline & Asal Daerah Responden & & \\
\hline 10 & Salatiga & 10 & 20,0 \\
\hline 11 & Banyubiru & 4 & 8,0 \\
\hline 12 & Ungaran & 3 & 6,0 \\
\hline 13 & Banyumanik & 4 & 8,0 \\
\hline 14 & Semarang & 20 & 40,0 \\
\hline 15 & Boyolali & 2 & 4,0 \\
\hline 16 & Sleman (DIY) & 6 & 12,0 \\
\hline \multirow[t]{3}{*}{17} & Temanggung & 1 & 2,0 \\
\hline & Total & 50 & 100 \\
\hline & Pendidikan & & \\
\hline 18 & SMP & 3 & 6,0 \\
\hline 19 & SLTA & 19 & 38,0 \\
\hline 20 & D3 & 10 & 20,0 \\
\hline 21 & $\mathrm{~S} 1$ & 14 & 28,0 \\
\hline \multirow[t]{3}{*}{22} & $\mathrm{~S} 2$ & 4 & 8,0 \\
\hline & Total & 50 & 100 \\
\hline & Pekerjaan Responden & & \\
\hline 23 & Pelajar & 7 & 14,0 \\
\hline 24 & Ibu Rumah Tangga & 9 & 18,0 \\
\hline 25 & Wiraswasta & 24 & 48,0 \\
\hline \multirow[t]{3}{*}{26} & PNS & 10 & 20,0 \\
\hline & Total & 50 & 100 \\
\hline & Penghasilan & & \\
\hline 27 & $0-1,499.999$ juta & 8 & 16,0 \\
\hline 28 & $1,500.000$ juta $-2,999.999$ juta & 15 & 30,0 \\
\hline 29 & 3.000 .000 juta $-4,499.999$ juta & 15 & 30,0 \\
\hline 30 & $4,500.000$ juta $-5,999.999$ juta & 7 & 14,0 \\
\hline 31 & 6.000.000juta -7.000 .000 juta & 2 & 4,0 \\
\hline \multirow[t]{3}{*}{32} & $>7.000 .000$ juta & 3 & 6,0 \\
\hline & Total & 50 & 100 \\
\hline & Jumlah Kunjungan & & \\
\hline 33 & 1 kali & 14 & 28,0 \\
\hline 34 & 2 kali & 24 & 48,0 \\
\hline 35 & 3 kali & 5 & 10,0 \\
\hline \multirow[t]{2}{*}{36} & $>4$ kali & 7 & 14,0 \\
\hline & Total & 50 & 100 \\
\hline
\end{tabular}

Sumber : Data primer diolah 2019 
Uji Validitas Variabel Penelitian

Uji validitas merupakan suatu cara yang harus dilakukan yang bertujuan untuk mengukur kevalidan data suatu penelitian. Pengujian yang dilakukan dalam penelitian ini bertujuan untuk mengukur skala instrumen pada masing-masing pernyataan setiap variabel, sehingga data yang diperoleh di lapangan bisa dinyatakan valid.

\section{Tabel-3 Hasil Uji Validitas}

\begin{tabular}{lcccc}
\hline Variabel Penelitian & Item & $\begin{array}{c}\text { Kofesien } \\
\text { Korelasi }\end{array}$ & r-Tabel & Keterangan \\
\hline Kualitas Pelayanan (X1) & X1.1 & 0,813 & 0,278 & Valid \\
& X1.2 & 0,809 & 0,278 & Valid \\
& X1.3 & 0,890 & 0,278 & Valid \\
& X1.4 & 0,679 & 0,278 & Valid \\
\hline Fasilitas (X2) & X2.1 & 0,752 & 0,278 & Valid \\
& X2.2 & 0,780 & 0,278 & Valid \\
& X2.3 & 0,737 & 0,278 & Valid \\
& X2.4 & 0,676 & 0,278 & Valid \\
\hline Lokasi (X3) & X3.1 & 0,685 & 0,278 & Valid \\
& X3.2 & 0,804 & 0,278 & Valid \\
& X3.3 & 0,858 & 0,278 & Valid \\
& X3.4 & 0,742 & 0,278 & Valid \\
\hline Promosi (X4) & X4.1 & 0,624 & 0,278 & Valid \\
& X4.2 & 0,736 & 0,278 & Valid \\
& X4.3 & 0,846 & 0,278 & Valid \\
& X4.4 & 0,628 & 0,278 & Valid \\
\hline Kepuasan Pengunjung (Y) & Y1 & 0,744 & 0,278 & Valid \\
& Y2 & 0,862 & 0,278 & Valid \\
& Y3 & 0,640 & 0,278 & Valid \\
& Y4 & 0,802 & 0,278 & Valid \\
\hline
\end{tabular}

Sumber : Data primer diolah, 2019

Pada tabel 4.13 dapat dilihat dari hasil pengujian validitas masing-masing variabel menunjukan nilai kofesien korelasi lebih besar dari $r$-tabel $=0,278$. Dengan $\mathrm{n}=50$ pada tingkat kepercayaan $0,05 \%$, sehingga setiap variabel dapat dinyatakan valid dan dapat dilanjutkan untuk pengujian selanjutnya.

\section{Uji Reliabilitas Variabel Penelitian}

Uji reliabilitas dalam penelitian ini digunakan untuk mengukur derajat kepercayaan pada suatu instrumen penelitian. Adapun pengujian reliabilitas digunakan untuk mengukur konstruk pernyataan pada setiap variabel sehingga dapat dinyatakan reliabel. 
Pada tabel 4.14 menunjukan bahwa hasil uji reliabilitas setiap indikator variabel penelitian mendapatkan nilai lebih besar dari 0,60 , sehingga dapat dikatakan bahwa setiap variabel sudah reliabel.

Tabel 4. Hasil Uji Reliabilitas

\begin{tabular}{lcc}
\hline \multicolumn{1}{c}{ Variabel Penelitian } & Cranbach's Alpha & Keterangan \\
\hline Kualitas Pelayanan (X1) & 0,810 & Reliabel \\
Fasilitas (X2) & 0,716 & Reliabel \\
Lokasi (X3) & 0,768 & Reliabel \\
Promosi (X4) & 0,661 & Reliabel \\
Kepuasan Pengunjung (Y) & 0,751 & Reliabel \\
\hline
\end{tabular}

Sumber : Data primer diolah, 201

Hubungan Kualitas Pelayanan (X1), Fasilitas (X2), Lokasi (X3) dan Promosi

(X4) Terhadap Kepuasan Pengunjung (Y)

Hubungan kualitas pelayanan, fasilitas, lokasi dan promosi terhadap kepuasan pengunjung agrowisata Kampoeng Banyumili, Kabupaten
Semarang. Dapat diketahui melalui uji korelasi rank spearman ( $\mathrm{r}_{\mathrm{s}}$ ), hasil analisis korelasi rank spearman terhadap setiap variabel Kualitas Pelayanan (X1), Fasilitas (X2), Lokasi (X3) dan Promosi (X4) terhadap Kepuasan Pengunjung (Y) dapat dilihat sebagai berikut :

Tabel 5. Hasil analisis korelasi rank spearman

\begin{tabular}{llcccc}
\hline No & \multicolumn{1}{c}{ Variabel } & $\begin{array}{c}\text { Kofisien } \\
\text { korelasi }\end{array}$ & Sig & Keterangan & Tingkat Hubungan \\
\hline 1 & Kualitas Pelayanan (X1) & $0,428^{* *}$ & 0,002 & Signifikan & Sedang \\
2 & Fasilitas (X2) & $0,400^{* *}$ & 0,004 & Signifikan & Sedang \\
3 & Lokasi (X3) & $0,621^{* *}$ & 0,000 & Signifikan & Kuat \\
4 & Promosi (X4) & $0,486^{* *}$ & 0,000 & Signifikan & Sedang \\
\hline \multicolumn{2}{l}{ Sumber : Data primer diolah, 2019 } & & &
\end{tabular}

Dapat dilihat pada tabel diatas menunjukan hasil dari analisis korelasi rank spearman bahwa hubungan Kualitas Pelayanan (X1), Fasilitas (X2), Lokasi (X3) dan promosi (X4) memiliki nilai Sig kurang dari 0,05 yang berarti semua variabel memiliki hubungan yang signifikan terhadap Kepuasan Pengunjung (Y).

Hubungan Kualitas Pelayanan (X1)

\section{Terhadap Kepuasan Pengunjung ( $Y$ )}

Dari hasil uji analisis korelasi rank spearman pada tabel 4.17 dapat diketahui 
bahwa koefesien korelasi variabel kualitas pelayanan (X1) terhadap kepuasan pengunjung (Y) memiliki nilai sebesar 0,428 dengan tanda positif dan signifikan dengan taraf kepercayaan 95\%. Hal ini menunjukan bahwa variabel kualitas pelayanan memiliki hubungan yang positif dengan tingkat hubungan sedang terhadap kepuasan pengunjung, dengan demikian kualitas pelayanan merupakan salah satu faktor yang membuat pengunjung merasa puas. Hal ini dikarenakan apabila pihak agrowisata menyediakan kualitas pelayanan yang baik maka, pengunjung akan merasa senang dengan apa yang mereka dapat dan rasakan di tempat agrowisata tersebut.

Melalui hasil wawancara dengan pengunjung yang datang ke lokasi mereka merasa puas dengan pelayanan yang diberikan oleh pihak agrowisata, saat pertamakali datang ke lokasi. Para pengunjung akan disambut dengan ramah oleh karyawan yang bertugas, saat pengunjung ingin menikmati fasilitas permainan yang ada karyawan juga cepat dan tanggap dalam menyediakan alat-alat keamanan yang dibutuhkan pada saat bermain. Selain itu sikap sopan yang ditunjukan kepada pengunjung baru maupun yang sudah sering datang sehingga membuat konsumen merasa puas dengan pelayanan diberikan.

Hal berikut sesuai dengan penelitian yang dilakukan Dewi Fatmasari (2018), bahwa kualitas pelayanan memiliki hubungan signifikan terhadap kepuasan pelanggan di Alfamart kelurahan wetan Kabupaten Semarang. Menurut Tjiptono (2004), Pelayanan yang baik membuat pengunjung menjadi puas sekaligus menjalin hubungan dengan konsumen sehingga pengunjung akan merasa nyaman dan tidak akan berpindah ke penyedia jasa lain. Jika suatu usaha jasa memiliki kualitas pelayanan yang buruk sehingga membuat pelanggan tidak puas akan berakibat fatal terhadap keberlangsungan usaha tersebut.

\section{Hubungan Fasilitas (X2) Terhadap}

\section{Kepuasan Pengunjung (Y)}

Dari hasil uji analisis korelasi rank spearman pada tabel 4.17 dapat diketahui bahwa koefesien korelasi variabel fasilitas (X2) terhadap kepuasan pengunjung (Y) memiliki nilai sebesar 0,400 dengan tanda positif dan signifikan dengan taraf kepercayaan 95\%. Hal tersebut menunjukan bahwa variabel fasilitas memiliki hubungan yang positif terhadap kepuasan pengunjung dan memiliki tingkat hubungan yang sedang, yang artinya variabel fasilitas merupakan salah satu 
faktor yang membuat pengunjung merasa puas pada saat berwisata. Dengan memiliki fasilitas yang lengkap suatu agrowisata dapat menjamin kenyamanan dan keselamatan para pengunjung, sehingga pengunjung merasa puas dengan fasilitas yang disediakan pihak agrowisata Kampoeng Banyumili.

Melalui hasil wawancara dengan pengunjung yang datang ke lokasi, mereka menganggap fasilitas seperti saung dan meja yang disediakan pihak agrowisata tertata dengan rapi serta nyaman sehingga dapat mendukung suasana saat menikmati hidangan makanan. Untuk fasilitas permainan pihak agrowisata menyediakan peralatan keamanan yang cukup lengkap, ini membuat pengunjung merasa aman saat menggunakan fasilitas permainan yang disediakan. Sedangkan fasilitas penunjang seperti toko oleh-oleh, mushola, toilet dan lain sebagainya sudah disediakan dalam memenuhi kebutuhan pengunjung saat datang berwisata.

Hal tersebut sesuai dengan penelitian yang dilakukan Santoso (2019), yang menyatakan bahwa fasilitas berhubungan secara signifikan terhadap kepuasan pengunjung agrowisata di PT Perkebunan Teh Tambi Kabupaten Wonosobo. Menurut Sumayang (2003), menyatakan bahwa fasilitas merupakan segala sesuatu yang disediakan untuk dipakai, dipergunakan, ditempati serta dinikmati oleh pengunjung yang datang. Apabila fasilitas yang tersedia pada usaha jasa diberikan sesuai dengan keinginan pengunjung maka pengunjung akan merasa puas dan menjadi loyal terhadap perusahaan.

\section{Hubungan Lokasi (X3) Terhadap Kepuasan Pengunjung (Y)}

Dari hasil uji analisis korelasi rank spearman pada tabel 4.17 dapat diketahui bahwa koefesien korelasi variabel lokasi (X3) terhadap kepuasan pengunjung (Y) memiliki nilai sebesar 0,621 dengan tanda positif dan signifikan dengan taraf kepercayaan 95\%. Hal tersebut menunjukan bahwa variabel fasilitas memiliki hubungan yang positif terhadap kepuasan pengunjung serta memiliki tingkat hubungan yang kuat. Ini berarti bahwa lokasi yang strategis, dekat dengan pemukiman warga dan memiliki visibilitas yang baik dan mudah dijangkau transportasi umum maupun pribadi membuat pengunjung merasa sangat puas. Melalui hasil wawancara dengan pengunjung yang datang dengan menggunakan kendaraan pribadi maupun kendaraan umum, mereka merasa puas karena lokasi Agrowisata Kampoeng Banyumili dekat dengan jalan raya. 
Sehingga mereka tidak sulit untuk menemukan lokasi agrowisata dan lahan parkir yang disediakan juga luas. Serta lokasi agrowista yang memiliki visibilitas yang baik, membuat para pengunjung dapat menikmati pemandangan keseluruhan wilayah agrowisata dengan nyaman, sembari menikmati hidangan yang disediakan. Hal ini tidak sejalan dengan penelitian Santoso (2019), yang menyatakan lokasi tidak memiliki hubungan yang signifikan terhadap kepuasan pengunjung agrowisata di PT Perkebunan Teh Tambi Kabupaten Wonosobo.

\section{Hubungan Promosi (X4) Terhadap}

\section{Kepuasan Pengunjung ( $Y$ )}

Dari hasil uji analisis korelasi rank spearman pada tabel 4.17 dapat diketahui bahwa koefesien korelasi variabel promosi (X4) terhadap kepuasan pengunjung (Y) memiliki nilai sebesar 0,486 dengan tanda positif dan signifikan dengan taraf kepercayaan 95\%. Hal tersebut menunjukan bahwa variabel fasilitas memiliki hubungan yang positif terhadap kepuasan pengunjung serta memiliki tingkat hubungan yang sedang. Artinya promosi yang diberikan pihak agrowisata melalui website, media massa maupun promosi penjualan seperti harga diskon, paket wisata dan sebagainya sudah sesuai dengan apa yang didapat serta dirasakan membuat pengunjung merasa puas.

Melalui hasil wawancara dengan pengunjung yang datang, rata-rata mereka mengetahui lokasi agrowisata Kampoeng Banyumili melalui teman, kerabat dan keluarga yang sudah pernah melakukan kunjungan sebelumnya. Serta melalui media massa seperti instagram dan facebook, pengunjung merasa apa yang diberitahukan sesuai dengan yang didapatkan setelah datang langsung ke lokasi agrowisata, serta banyak promo dan paket wisata yang disediakan pihak agrowisata Kampoeng Banyumili.

Hal tersebut sesuai dengan penelitian Yuyun Mardiyanti (2015) yang menyatakan bahwa promosi berpengaruh signifikan terhadap keputusan berkunjung. Menurut Tjiptono (2008), promosi merupakan jenis kegiatan yang ditujukan untuk mendorong permintaan dan penyampaian informasi dari penyedia jasa kepada pembeli untuk mempengaruhi keputusan dalam memilih suatu produk atau jasa yang disediakan pihak perusahaan agar menciptakan pertukaran.

\section{Analisis Dinamika Usaha} Agrowisata Kampoeng Banyumili

Wawancara dilakukan dengan tokoh kunci (key informant) yaitu Bapak Muhamad Sauqi selaku GM (General 
Manager) sekaligus pemilik usaha agrowisata Kampoeng Banyumili. Adapun informant yaitu Bapak Aji Septianto selaku supervisi pelayanan dan pengadaan stok sekaligus karyawan yang paling lama bekerja di Agrowisata Kampoeng Banyumili, untuk mengetahui dinamika atau tahapan-tahapan yang telah dilalui usaha agrowisata Kampoeng Banyumili.

\section{Tahap Eksplorasi}

Agrowisata Kampoeng Banyumili awalnya merupakan lokasi bermain dan memancing yang dibuat hanya untuk keluarga, kemudian mendapat banyak respon positif dari tamu yang bekunjung. Hal ini akhirnya membuat Bapak Sauqi memiliki ide untuk mengembangkan lokasi yang dimilikinya menjadi suatu usaha, dengan konsep wisata alam yang cenderung kearah edukasi. Hal tersebut membuat terbukanya lapangan pekerjaan dan usaha baru yang bermanfaat bagi masyarakat sekitar, walaupun dengan usia yang sudah tidak produktif masih bisa mendapat pekerjaan. Adapun kedepannya usaha ini akan terus dikembangkan, melihat banyaknya peminat yang ingin berkunjung ke lokasi agrowisata Kampoeng Banyumili.

\section{Tahap Pengembangan}

Pada tahapan ini pihak agrowisata lebih mengutamakan kenyamanan pengunjung pada saat berwisata, mulai dari menjaga kebersihan fasilitas, pelayanan yang baik, kebersihan dan kesehatan makanan. Hal ini yang membuat pengunjung merasa puas pada saat berwisata. Adapun sistem penjualan dan pengadaan stok akan terus diperbaiki serta perluasan wilayah akan terus dilakukan sehingga usaha agrowisata Kampoeng Banyumili semakin ramai dikunjungi. Dari pengembangan lokasi agrowisata Kampoeng Banyumili memberikan manfaat secara langsung kepada masyarakat sekitar seperti menjadi karyawan dan pemasok bahan makanan, sehingga secara tidak langsung desa menjadi ramai, serta membuka peluang usaha bagi masyarakat sekitar.

\section{Tahap Kestabilan}

Pengunjung yang datang ke Agrowisata Kampoeng Banyumili tidak hanya berasal dari dalam kota, tetapi juga banyak yang berasal dari luar kota seperti Jakarta, Surabaya dan Jogja. Hal ini dikarenakan pengunjung yang penat dengan hiruk pikuk perkotaan, sehingga agrowisata Kampoeng Banyumili yang menawarkan suasana persawahan yang dipadukan dengan resto menjadi salah satu 
solusi bagi pengunjung yang berasal dari wilayah perkotaan. Hal tersebut menunjukan bahwa agrowisata Kampoeng Banyumili belum mengalami penurunan jumlah pengunjung, dengan mengutamakan kepuasan pengunjung masih menjadi kunci agrowisata Kampoeng Banyumili untuk terus mempertahankan popularitasnya.

\section{Tahap Penurunan Kualitas}

Agrowisata Kampoeng Banyumili sampai tahun ini belum mengalami penurunan jumlah pengunjung, ini dibuktikan dengan penambahan fasilitas serta pelebaran wilayah yang sudah dilakukan membuat pengunjung tidak merasa jenuh. Oleh karenanya pengunjung yang sudah datang sering melakukan kunjungan ulang, bahkan sampai merekomendasikan kepada keluarga dan kerabat. Artinya lokasi agrowisata Kampoeng Banyumili belum berada pada tahapan ini.

\section{Tahap Peremajaan Kembali}

Agrowisata Kampoeng Banyumili belum berada pada tahapan ini, pihak agrowisata Kampoeng Banyumili masih fokus untuk terus melakukan perbaikan di bagian pelayanan, makanan dan fasilitas. Adapun beberapa rencana terobosan sudah dibuat seperti penambahan wilayah, wahana bermain dan bangunan tempo dulu untuk mempertahankan popularitas agrowisata Kampoeng Banyumili serta agar semakin ramai dikunjungi.

\section{KESIMPULAN DAN SARAN}

\section{Kesimpulan}

Berdasarkan hasil dan pembahasan penelitian tentang dinamika usaha dan kepuasan pengunjung agrowisata Kampoeng Banyumili maka dapat disimpulkan bahwa :

1. variabel yang memiliki tingkat hubungan yang sedang dan positif serta berkorelasi signifikan terhadap kepuasan pengunjung (Y) adalah Kualitas Pelayanan (X1), Fasilitas (X2), Promosi (X4). Tindakan seperti penambahan fasilitas penunjang dan mengevaluasi sekaligus memperbaiki setiap bagian pekerjaan dapat meningkatkan kepuasan pengunjung.

2. Sedangkan variabel Lokasi (X3) memiliki tingkat hubungan yang kuat dan positif serta berkorelasi signifikan terhadap Kepuasan Pengunjung (Y). Lokasi yang dekat dengan jalan raya sehingga mudah dijangkau transportasi umum maupun pribadi, sehingga menjadi faktor penting yang menentukan keputusan berkunjung responden. 
3. Dari siklus atau dinamika usaha, Agrowisata Kampoeng Banyumili sedang berada pada tahap kestabilan. Adapun tahap penurunan kualitas dan peremajaan kembali, belum terjadi pada agrowisata Kampoeng Banyumili.

\section{Saran}

1. Pihak agrowisata Kampoeng Banyumili hendaknya melakukan perbaikan terhadap penunjuk arah, karena pengunjung yang baru pertama kali datang berwisata kesulitan untuk menemukan letak fasilitas yang ingin mereka nikmati atau yang sudah mereka pesan.

2. Akademisi yang ingin melakukan penelitian lanjutan hendaknya memperhatikan variabel harga, yang dipertimbangkan konsumen dalam memutuskan untuk berkunjung ke Agrowisata Kampoeng Banyumili.

3. Untuk tetap berada pada tahap kestabilan Agrowisata Kampoeng Banyumili harus selalu memberikan pelayanan yang terbaik dan membuat terobosan baru sehingga pengunjung tidak merasa bosan dan tetap loyal.

\section{'DAFTAR PUSTAKA}

Angreini, T. D. (2015). Pengaruh Kualitas Pelayanan Terhadap Kepuasan Pengunjung Agrowisata PT
Godongijo Asri Dalam Membentuk Minat Berkunjung Ulang. Skripsi Program Sarjana Alih Jenis Agribisnis Fakultas Ekonomi dan Manajemen Institut Pertanian. Bogor.

Lopez, E. P. (2006). Agrotourism, sustainable tourism and Ultraperipheral areas. The Case of Canary Islands Journal 4(1):, 85-97.

BPS. (2019). Jumlah Wisatawan Mancanegara dan Domestik di Provinsi Jawa Tengah Periode Tahun 2011 - 2015. https://jateng.bps.go.id. Diakses Pada Tanggal 14 Juli 2019: Salatiga.

Kurniati, A. W. (2018). Strategi Komunikasi Pemasaran Digital Sebagai Penggerak Desa Wisata Kabupaten Wonosobo Provinsi Jawa Tengah. Jurnal Riset Komunikasi.

Sugiyono. (2014). Metode Penelitian Kuantitatif, Kualitatif Dan $R \& D$. Bandung: Penerbit Alfa.

Sugiyono. (2009). Analisis Metode Penelitian Kualitatif Dan Kuantitatif. Jakarta: Penerbit Bina Pustaka.

Sugiyono. (2011). Metode Penelitian Kualitatif Dan Kuantitatif $R \& D$ Cetakan Ke 13. Bandung: Alfabeta.

Sugiyono. (2013). Metode Penelitian Kuantitatif, Kualitatif Dan $R \& D$. Bandung: Alfabeta.

Tjiptono. (2008). Strategi Pemasaran. Edisi ke 3. Yogyakarta: Andy.

Mardiyanti, Y. (2015). Pengaruh Fasilitas Dan Promosi Terhadap Kepuasan Pengunjung Melalui Keputusan Berkunjung Sebagai Variabel Intervening Pada Objek Wisata Kota Semarang. Management Analysis Journal, 4(1).

Santoso, I. (2019). Hubungan Fasilitas, Kualitas Pelayanan, Harga, dan Tempat Terhadap Kepuasan Pengunjung Agrowisata di PT Perkebunan Teh Tambi Kabupaten 
Wonosobo. Skripsi Fakultas Pertanian. Universitas Kristen Satya Wacana.

Sumayang, L. (2003). Dasar-Dasar Manajemen Produksi dan Operasi. Jakarta: Salemba Empat.

Tjiptono. (2004). Pemasaran Jasa. Malang: Banyumedia.
Dewi Fatmasari, F. (2018). Hubungan Kualitas Pelayanan Dengan Kepuasan Pelanggan Alfamart Di Kelurahan Serondol Wetan Semarang. Majalah Ilmiah Inspiratif, Vol. 3 No. 5 